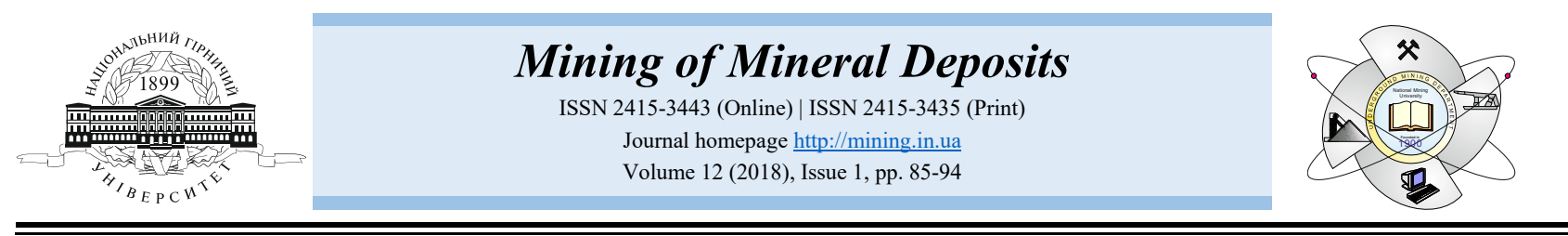

UDC 622.013

https://doi.org/10.15407/mining12.01.085

\title{
EXPLORATION AND MINING EVALUATION SYSTEM AND PRICE PREDICTION OF URANIUM RESOURCES
}

\author{
J. Chen ${ }^{1 *}$, Y. Zhao ${ }^{1}$, Q. Song ${ }^{1}$, Z. Zhou ${ }^{1}$, S. Yang ${ }^{1}$ \\ ${ }^{1}$ Central South University, Changsha, China \\ *Corresponding author: e-mail cjh@263.net, tel. +86073188830534, fax: +86073188879612
}

\begin{abstract}
Purpose. The paper introduces the development of the Uranium Resources Technical and Economic Evaluation Expert System (URTEEES) from the viewpoint of requirement analysis, system design, functional structure and application etc.
\end{abstract}

Methods. The system is based on $\mathrm{C} / \mathrm{B} / \mathrm{S}$ mixed mode and applies ASP.NET technology with .Net Framework being selected as the development platform as well as the uranium resources database providing data support at the bottom layer. The paper also proves the efficiency of the system in the context of certain case studies.

Findings. Since the system can performs the functions of scenario analysis, sensitivity analysis, shareholder's returns analysis, horizontal comparison of different projects, it can improve the ability of project senior decision-makers for rapid response to the rivals and meet the demand of pricing negotiations. Moreover, the system demonstrates its efficiency in the context of case studies as the system incorporates a number of advanced methods, e.g. the Quantum Particle Swarm Optimization (QPSO) Back Propagation (BP) QPSO-BP model which can improve the generalization ability of BP network to predict the uranium price.

Originality. Technical and economic evaluation model can be set up by users independently according to the current stage of a project (mainly, these are exploration stage, development stage and production stage) as well as according to the selected mining method (e.g. underground mining, surface mining, or in-situ leaching mining). Then, the technical and economic evaluation parameters can be generated. By means of inputting the value of each parameter in a simple and convenient way, the evaluation results can be calculated directly and shown in the form of diagrams; moreover, feasibility evaluation report can be generated automatically, making the process of technical and economic evaluation accurate and efficient.

Practical implications. URTEEES performs the functions of decision-making analysis, metal resources database management, data management, comprehensive query etc. The system is a good basis for further development of other expert systems.

Keywords: uranium resources, expert system, $C / B / S$ mixed mode, quantum particle swarm optimization, algorithm, QPSO-BP model

\section{INTRODUCTION}

With the arrival of a new round of industrialization upsurge in both developing and developed countries, growth of demand for uranium resources is entering a new stage. Population involved in the new industrialized countries is about four times that of all previous industrialized countries, implying resource consumption increases dramatically both in speed and in quantity. It is a must to seize the strategic opportunity of developing and utilizing uranium resources around the world to lay abundant resource base for national industrialization. Objectively speaking, global configuration of metal resources is an inevitable tend. Presently, many issues, for example, resources exploration, mining, merge of mining companies, uranium trades, mining financing, etc., generally show the feature of globalization. For the reality that competition for uranium resources is becoming fiercer, industry standards of mineral resources will undoubtedly be improved. Occupying large scale mineral resources with high grade and developing them with low cost is the base for the survival of mining companies and uranium resources merchants. With the growing demand of global investment in mineral resources exploration, which is at the upstream of the industry chain, geological exploration industry is promising. Globally building

(C) 2018. J. Chen, Y. Zhao, Q. Song, Z. Zhou, S. Yang. Published by the National Mining University on behalf of Mining of Mineral Deposits.

This is an Open Access article distributed under the terms of the Creative Commons Attribution License (http://creativecommons.org/licenses/by/4.0/),

which permits unrestricted reuse, distribution, and reproduction in any medium, provided the original work is properly cited. 
market relationships for mineral resources exploration companies is key to their sustainable development. Developing large and super-large deposit with low cost is also an important approach to enhancing core competence of a country or an enterprise. Mining companies around the world are rushing to purchase mineral resources globally. However, in different countries, economic, financial and tax systems for mineral resources vary greatly, and mining and processing techniques, technical parameters and equipment selection also change a lot. Thus, pro-phase research work is necessary for feasibility evaluation of mineral resources projects and it can be time wasting if taken in the traditional way. It is necessary to accelerate the process considering the complex and rapidly changing international situation.

Expert system is a useful tool for applying domain expert's knowledge and experience to help solve problems efficiently in the domain and has been widely used in almost all areas especially in business and manufacturing industry (Gong, John, \& Gong, 2014). Expert system can act as either substitute or assistance of human experts with its abilities of interpretation, predication, diagnosis, design, planning, monitoring, control, debugging, instruction, repair, decision making, consultation and so on. Researchers from different domains have made efforts on developing expert systems (Ertl \& Christ, 2007; Iqbal, He, Li, \& Dar, 2007; Polat \& Güneş, 2007; Ebersbach \& Peng, 2008; Wen, 2008; Koutsantonis \& Panayiotopoulos, 2009; Zarandi \& Ahmadpour, 2009; Dymova, Sevastianov, \& Bartosiewicz, 2010; Wen, 2010; Castellanos, Albiter, Hernández, \& Barrera, 2011; Ruiz-Mezcua, Garcia-Crespo, Lopez-Cuadrado, \& Gonzalez-Carrasco, 2011; Šubelj, Furlan, \& Bajec, 2011; Piltan, Mehmanchi, \& Ghaderi, 2012; Wan, Lei, \& Chou, 2012; Kim, Roh, \& Ha, 2015; Marlow, Gould, \& Lane, 2015). Applications of expert system show its efficiency and much more work should be done for its further development and application. To meet the demand of efficiently and accurately achieving investment feasibility evaluation of uranium resources projects, URTEEES is developed. This paper aims to introduce the development process of the expert system in the aspects of requirements analysis, design of the expert system, main functions of the expert system and features of the expert system.

\section{REQUIREMENT ANALYSIS}

\subsection{Standardization of financial valuation model}

There exists much difference in the links of cost occurring with regard to different mining and processing methods. Thus, many financial valuation models, namely for example, investment estimation models and cost models, should be established respectively for different projects to achieve standardization of the valuation process. The models should meet the demand of accurate financial valuation for different type of projects that are classified according to at which stage a project is, mainly including exploration stage, development stage and production stage, and according to the mining methods, for example underground mining, surface mining and in-situ leaching mining.

\subsection{Multiple technical and economic evaluation methods for uranium mine}

Uranium resources technical and economic evaluation methods should be selected and organized systematically. The methods should meet the demand of achieving appropriate technical and economic evaluation for different type of projects by considering the evaluation purposes and characteristics of the evaluation parameters.

\subsection{Database for uranium resources evaluation}

The database should include the basic two parts. One is the existing data about uranium resources evaluation for obtaining the related evaluation parameters that can be used for setting up evaluation models and providing the basis for comparison when a new project is to be evaluated. The other is the supporting information, such as laws and regulations, cultural information, which is actually the accumulation of project data and experience.

\section{SYSTEM DESIGN}

\subsection{System deployment}

System deployment is mainly composed of the client side and the server side. Logical architecture of the system is shown in Figure 1.

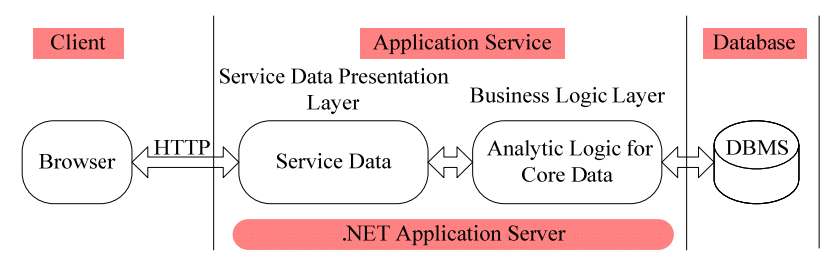

Figure 1. Logical architecture of URTEEES

At the server side, data related to uranium resources projects and other auxiliary information are stored with Data Base Management System (DBMS). At the client side, users can access to the server by using the browser.

\subsection{System overall structure}

The system adopts both $\mathrm{B} / \mathrm{S}$ mode and $\mathrm{C} / \mathrm{S}$ mode for data access, thus is based on $\mathrm{C} / \mathrm{B} / \mathrm{S}$ mixed mode. $\mathrm{B} / \mathrm{S}$ mode is mainly used for comprehensive query of information and $\mathrm{C} / \mathrm{S}$ mode for processing table data and outputting report forms. ASP.NET technology is also used by the system and specific functional modules are developed on the .Net Framework platform. Uranium resources database provides data support for the system at the bottom layer. The technologies guarantee universality, flexibility and maintainability of the system.

\subsection{System functional structure}

URTEEES is an auxiliary system for enterprise management by assisting decision analysis and supporting project management. A project model can be set up by the importing function of the system or by using the default models in the system. Then technical and economic evaluation of the model can be carried out by determining the related evaluation parameters and choosing proper evaluation methods. 
Data related to uranium resources can be stored in the database. Users can be assigned different access permissions to the database for performing operations like query and download. The system mainly has the functions of decision-making analysis, uranium resources database management, data management and comprehensive query as shown in Figure 2.

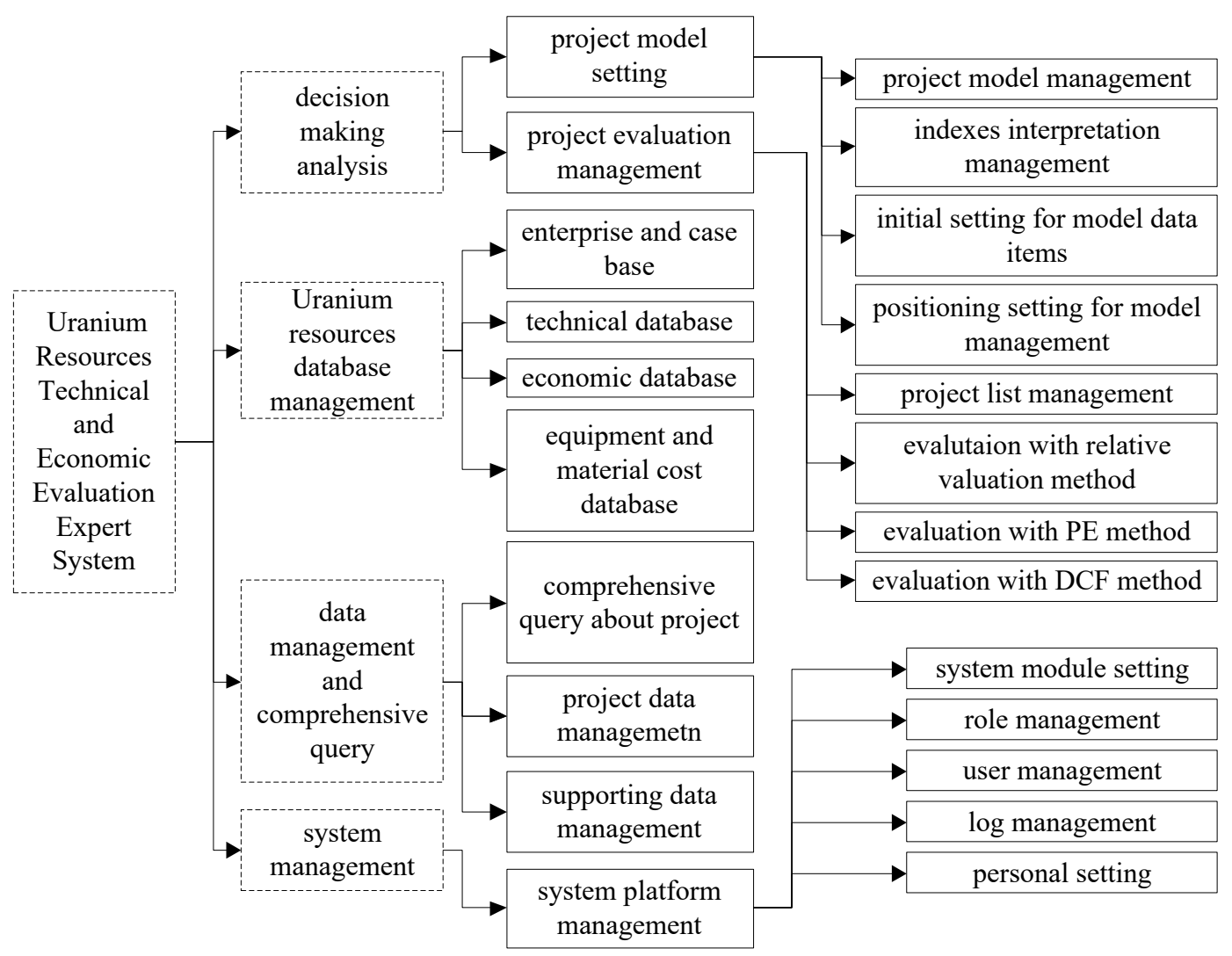

Figure 2. Functional structure of MRTEEES

For the module project model setting, the following items are set.

1. Definition and interpretation of basic evaluation parameters fine items and annual parameters.

2. Rules for judging data abnormal.

3. Logical relationships for incidence query based on key words of parameters or other items.

For the module project evaluation management, evaluation methods are gathered for selection in decision making analysis. The methods include relative valuation method, price-earnings ratio (PE) method and Discounted Cash Flow (DCF) method among other methods.

\section{INTRODUCTION TO MAIN FUNCTIONS}

\subsection{Metal resources database management}

Accuracy of the decision-making analysis results relies on truthfulness and timely updating of the technical parameters, economic parameters and cost parameters. Uranium resources database is to provide data support for URTEEES. It includes four databases namely enterprise and case database, technical database, economic database and cost database. Again, taking uranium resources database for example, and Table 1 lists the main subdatabases of the four databases. Data in the sub-databases are stored in the form of tables. A user can perform operations like adding data, modifying data or deleting data for data in each cell within the user' permission scope. Such data as price of metals, interest rate and exchange rate change frequently and need to be updated timely.

\subsection{Data management}

Data management mainly includes project data management and supporting data management. Project data management is related to a project's due diligence, project approval application, feasibility report, feasibility study report, feasibility study report, preliminary design report. Supporting data management is about corresponding laws and regulations, research report, social and cultural information, etc.

\subsection{Project comprehensive query}

Project comprehensive query means searching for the information of parameters or indexes of different project model. The system allows comprehensive query for abundant contents, for example, basic parameters of project, hydrometallurgy cost details of exploration project, comprehensive estimation of geological exploration, investment estimation of mine construction, cost estimation of other engineering construction, cost estimation, wage estimation and main indexes of project. There are two methods of querying. One is classification query by selecting the corresponding items under each category. The other is filtering query by using key words directly. 
Table 1. Uranium resources database and sub-database

\begin{tabular}{|c|c|c|c|}
\hline $\begin{array}{c}\text { Enterprise } \\
\text { and case database }\end{array}$ & Technical database & Economic database & Cost database \\
\hline $\begin{array}{c}\text { Country } \\
\text { or district data }\end{array}$ & \multirow{7}{*}{$\begin{array}{c}\text { Hydrometallurgical } \\
\text { mill database } \\
\text { Uranium-ore } \\
\text { deposit database }\end{array}$} & Uranium price database & $\begin{array}{c}\text { Database of raw and auxiliary } \\
\text { materials for mining }\end{array}$ \\
\hline Enterprise database & & Exchange rate database & $\begin{array}{l}\text { Database of raw and auxiliary } \\
\text { materials for hydrometallurgy }\end{array}$ \\
\hline \multirow[t]{5}{*}{ Trade case database } & & Interest rate database & $\begin{array}{l}\text { Database of equipment for } \\
\text { underground mining }\end{array}$ \\
\hline & & Tax profile of each country & $\begin{array}{l}\text { Database of equipment } \\
\text { for surface mining }\end{array}$ \\
\hline & & $\begin{array}{l}\text { Database of country } \\
\text { related to tax agreement }\end{array}$ & $\begin{array}{l}\text { Database of equipment } \\
\text { for hydrometallurgy }\end{array}$ \\
\hline & & Tax database of key country & $\begin{array}{l}\text { Database of general drawing } \\
\text { for transportation equipment }\end{array}$ \\
\hline & & $\begin{array}{c}\text { Economic database of each } \\
\text { country from World Bank } \\
\text { Database of macro } \\
\text { situation of Canada } \\
\text { Database of macro } \\
\text { situation of China }\end{array}$ & \\
\hline
\end{tabular}

\subsection{System management}

System management includes the following issues:

1. Defining modules and classes of the system.

2. Recording logs of logging and operation.

3. Personalized setting for interface skin and shortcut menu.

4. User management.

For user management, firstly user roles are defined, and corresponding role permissions are set. Then, a user role is directly assigned to a user and the user can per-form operations on the system within the role's permis-sions. Both user role setting and user role assignment setting are self-defined, making the user role levels unlimited.

\subsection{Decision making analysis}

Decision making analysis should be conducted based on a complete project model i.e. a series of interrelated computation sheets. To improve the modeling efficiency, URTEEES can be used for achieving standardization of the modeling process.

A project model can be easily set up by controlling the parameter inputting interface as well as with the data positioning setting within the related computation sheets. The input parameters should be tested before they are used for calculation so as to guarantee accuracy of the input data, which can be achieved through the function module of abnormal data analysis. The function module of incidence query allows knowing about the value and other information of a parameter according to its initial setting in the default models or other project models. The basic process for project model evaluation is shown in Figure 3. It should be noted that incidence query can associate with not only uranium resources database but also other databases in the system.

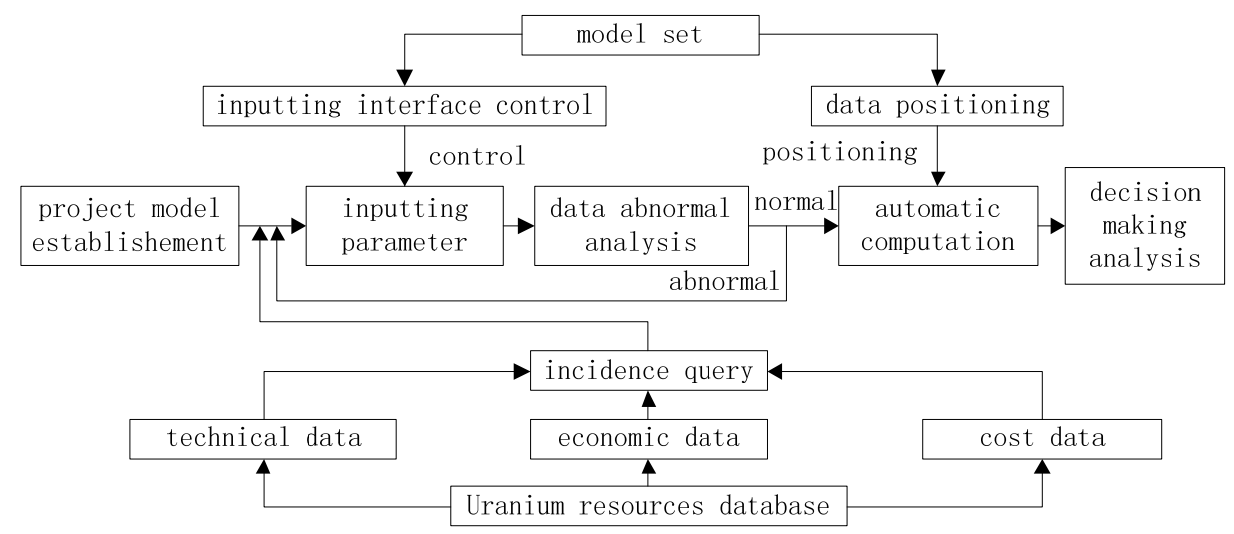

Figure 3. Basic process for project model evaluation

A variety of charts can be generated for a set of data. Taking uranium project for example. Figure 4 and 5 are respectively stacked chart and line chart for the results of sensitivity analysis with DCF method and can be used for analyzing the influence of different sensitivity factors on shareholder's Internal Rate of Return (IRR). In Figure 4, the horizontal axis represents the accumulated effect of each factor with each change rate and the vertical axis lists each factor. Length of the stacked strip represents sensitivity of each factor for its influence on shareholder's IRR. In Figure 5, the horizontal axis represents the change scale of each factor and the vertical axis represents the change rate of shareholder's IRR under the influence of each factor. Slope of each line represents the impact weight of the corresponding factor. According to the charts, sensitivity declines as the following sequence: uranium price, uranium (332) resources quantity, infrastructure investment, unit mining cost and soda price. 


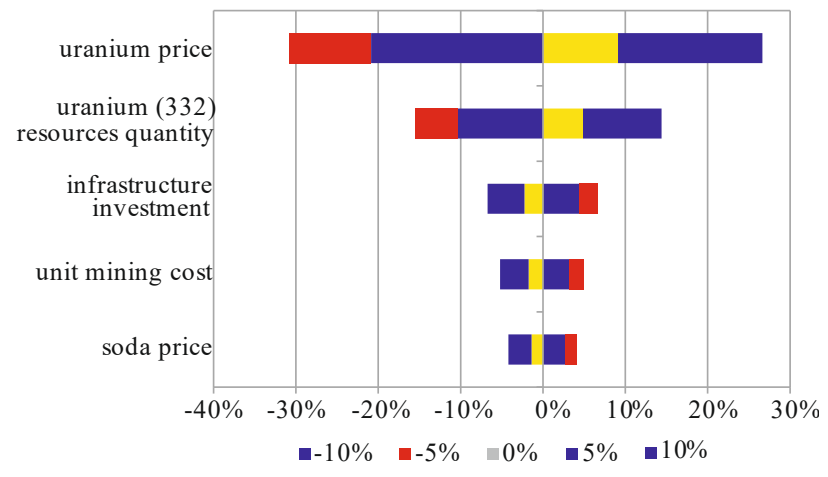

Figure 4. Sensitivity analysis results shown in stacked chart for uranium project with DCF method

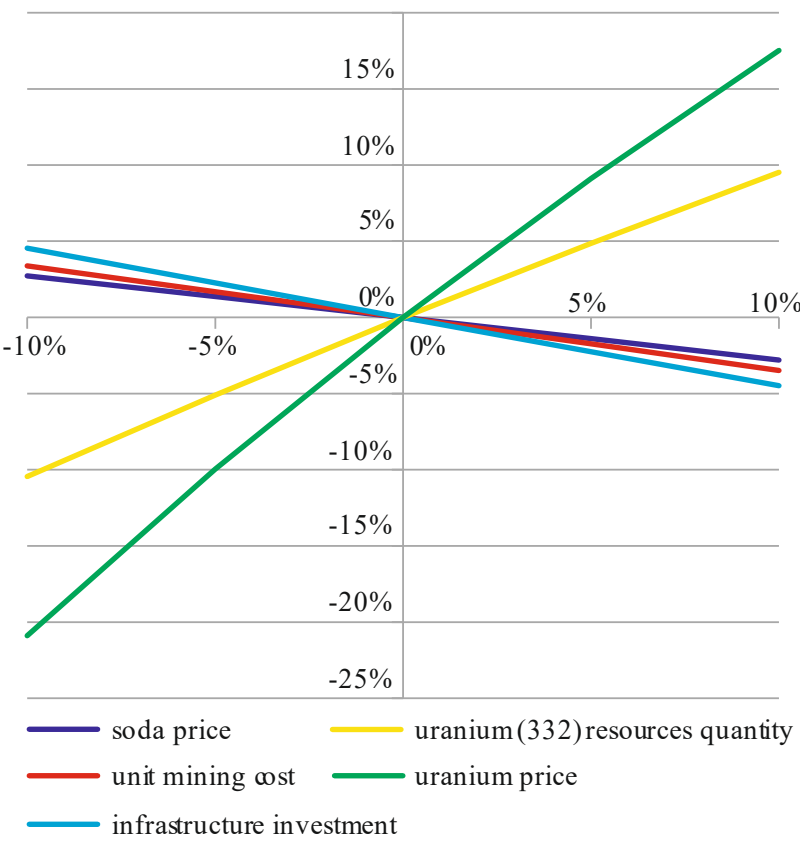

Figure 5. Sensitivity analysis results shown in line chart for uranium project with DCF method

Figure 6 is a bubble chart that shows Net Present Value (NPV), shareholder's IRR and total output of different uranium resources projects.

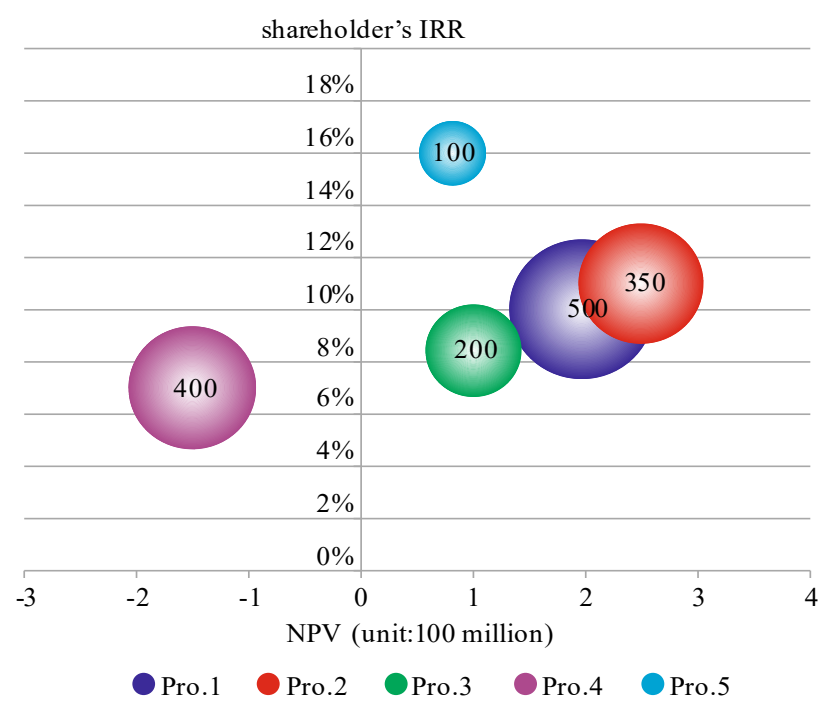

Figure 6. Project evaluation results shown in bubble chart for horizontal comparison
There are five projects namely Pro.1, Pro.2, Pro.3, Pro.4, Pro.5 respectively. The horizontal axis represents NPV in the unit of one hundred million, the vertical axis represents shareholder's IRR, the size of each bubble represents the total output of the corresponding project which is written on each bubble in number. The chart is for horizontal comparison of different projects. The most suitable project is determined according to whether it can best satisfy the present situation of a company. For example, though Pro.4 has the least IRR, it has the biggest total output. Considering the fact that uranium is scarce and price fluctuation of the metal is obvious, Pro.4 is the most suitable one for a company whose profit situation is good.

In addition, a very advanced uranium price prediction algorithm is applied in this system, which will be presented in details in chapter 5 .

\section{URANIUM PRICE PREDICTION}

\subsection{Uranium Price Prediction Model Based on QPSO-BP}

The uranium price prediction model is based on QPSO-BP. This model uses the Quantum Particle Swarm Optimization (QPSO) to optimize the initial value of weights $(W)$ and threshold $(V)$ of BP network. The position vector of the particle individual searched in global space is encoded as the best optimized value of weights and threshold and used in the 5-11-1 streamlined structure to predict the price of $\mathrm{U}_{3} \mathrm{O}_{8}$. The basic algorithm flow is as follows:

1. Set the input vector and the expected output vector. This step includes two parts. First is data processing (as shown in Table 2). The sample is reconstructed by rolling method, i.e. the previous $N$ values are used to predict the following $M$ values. Second is original data sequence $x(t)$ is normalization (as shown in Formula 1$)$. $\min (t)$ and $\max (t)$ are respectively the minimum and maximum values.

Table 2. Method of data processing

\begin{tabular}{cc}
\hline$N$ inputs & $M$ outputs \\
\hline$X_{1}, X_{2}, \ldots, X_{N}$ & $X_{N+1}, X_{N+2}, \ldots, X_{N+M}$ \\
$X_{2}, X_{3}, \ldots, X_{N+1}$ & $X_{N+2}, X_{N+3}, \ldots, X_{N+M+1}$ \\
$\ldots$ & $\ldots$ \\
$X_{K}, X_{K+1}, \ldots, X_{N+K}$ & $X_{N+K}, X_{N+K+1}, \ldots X_{N+M+K-1}$ \\
\hline
\end{tabular}

$X(t)=\frac{X(t)-\min (t)}{\max (t)-\min (t)}$.

2. Determine the nodes number of input layer, hidden layer and output layer of BP network.

3. The particle swarm initialization. Set the number of particles $(M)$, the length $(L)$ of the particle vector $(X)$, the fitness value of the target (fitness), maximum iteration (maxiter) and the particle velocity vector dimension $(D)$.

4. The fitness function determination; fitness is calculated by Formula 2 to evaluate the search performance of model:

fitness $=\frac{1}{p} \sum_{i=1}^{p} \sum_{i=1}^{n}\left\|d_{i, j}-t_{i, j}\right\|^{2}$. 
Let $g$ represent the maximum training error of the network. The learning process ends when fitness $\leq g$ or the process meets the maximum number of iterations. Otherwise, $N=N+1$, return to step 4) to continue the iteration where the values of the connection weight and the threshold value are used as the initial value for network training, and the new input sample is predicted with the current trained network.

\subsection{The practical application}

In the environment of MATLAB R2010a, the training and prediction process was designed to improve the efficiency of prediction. The data is from the price data of uranium $\left(\mathrm{U}_{3} \mathrm{O}_{8}\right)$ provided by the Millennium (Millennium) project of A uranium industry development co. LTD from May 2004 to May 2011, as shown in Table 3.

Table 3. Model training sample set

\begin{tabular}{|c|c|c|c|c|c|c|c|}
\hline Time & Price, $\$ / \mathrm{lb}$ & Time & Price, $\$ / \mathrm{lb}$ & Time & Price, $\$ / \mathrm{lb}$ & Time & Price, $\$ / 1 b$ \\
\hline $2004-1-26$ & - & $2006-1-30$ & 37.00 & $2008-1-28$ & 95.00 & $2010-1-25$ & 62.00 \\
\hline $2004-2-23$ & - & $2006-2-27$ & 40.00 & $2008-2-25$ & 95.00 & $2010-2-22$ & 60.00 \\
\hline $2004-3-29$ & - & $2006-3-27$ & 42.00 & $2008-3-31$ & 95.00 & $2010-3-29$ & 58.00 \\
\hline 2004-4-26 & - & $2006-4-24$ & 43.50 & $2008-4-28$ & 90.00 & $2010-4-26$ & 58.00 \\
\hline $2004-5-31$ & 18.00 & $2006-5-29$ & 46.50 & $2008-5-26$ & 90.00 & $2010-5-31$ & 58.00 \\
\hline 2004-6-28 & 19.00 & $2006-6-26$ & 46.50 & $2008-6-30$ & 80.00 & $2010-6-28$ & 58.00 \\
\hline $2004-7-26$ & 19.00 & $2006-7-31$ & 47.50 & $2008-7-28$ & 80.00 & $2010-7-26$ & 60.00 \\
\hline 2004-8-30 & 23.00 & $2006-8-28$ & 51.00 & $2008-8-25$ & 80.00 & $2010-8-30$ & 60.00 \\
\hline $2004-9-27$ & 23.00 & $2006-9-25$ & 54.00 & $2008-9-29$ & 75.00 & $2010-9-27$ & 60.00 \\
\hline $2004-10-25$ & 23.50 & 2006-10-30 & 58.00 & $2008-10-31$ & 70.00 & $2010-10-25$ & 62.00 \\
\hline $2004-11-29$ & 25.00 & 2006-11-27 & 58.00 & $2008-11-24$ & 70.00 & 2010-11-29 & 65.00 \\
\hline $2004-12-27$ & 25.00 & $2006-12-25$ & 75.00 & $2008-12-29$ & 70.00 & $2010-12-27$ & 65.00 \\
\hline $2005-1-31$ & 26.00 & $2007-1-29$ & 75.00 & $2009-1-26$ & 70.00 & 2011-1-31 & 73.00 \\
\hline $2005-2-28$ & 27.00 & $2007-2-26$ & 85.00 & $2009-2-23$ & 70.00 & $2011-2-28$ & 73.00 \\
\hline $2005-3-28$ & 27.00 & $2007-3-26$ & 85.00 & $2009-3-30$ & 70.00 & 2011-3-28 & 72.00 \\
\hline $2005-4-25$ & 28.00 & $2007-4-30$ & 85.00 & $2009-4-27$ & 65.00 & 2011-4-25 & 70.00 \\
\hline $2005-5-30$ & 30.00 & $2007-5-28$ & 95.00 & $2009-5-25$ & 65.00 & 2011-5-30 & 68.00 \\
\hline $2005-6-27$ & 30.00 & $2007-6-25$ & 95.00 & $2009-6-29$ & 65.00 & & \\
\hline $2005-7-25$ & 31.00 & $2007-7-30$ & 95.00 & $2009-7-27$ & 65.00 & & \\
\hline $2005-8-29$ & 32.00 & $2007-8-27$ & 95.00 & $2009-8-31$ & 64.00 & & \\
\hline $2005-9-26$ & 33.00 & $2007-9-24$ & 95.00 & $2009-9-28$ & 64.00 & & \\
\hline $2005-10-31$ & 34.00 & 2007-10-29 & 95.00 & $2009-10-26$ & 64.00 & & \\
\hline $2005-11-28$ & 34.50 & $2007-11-26$ & 95.00 & $2009-11-30$ & 62.00 & & \\
\hline $2005-12-26$ & 36.25 & 2007-12-31 & 95.00 & $2009-12-28$ & 62.00 & & \\
\hline
\end{tabular}

The data of the sample set in Table 2 is divided according to Table 1. $N=5, K=75, M=1$, divided into 80 data segments with length 6 , according to formula 1 to normalize the data. The number of network input nodes is 5 . According to the number of implicit layers: $N_{i}=2 N+1$. Select the hidden layer node number 11 and the output node is the predicted value of uranium price. Therefore, the network structure is 5-11-1.

In the process of training and testing the network, the more groups of training samples can improve the prediction accuracy of the network. The first 75 sets of data were used as samples of training, and the last five sets of data were tested as samples. Input the sample to the network for training.

There are 1560 parameters to be optimized by the neural network 5-11-1 structure:

$$
\begin{aligned}
& X_{i, j}=\left[X_{1,1}, X_{1,2}, \ldots, X_{i, j}\right] \\
& i=1,2, \ldots, 20 ; j=1,2, \ldots, 78 \\
& W=\left[W_{1}, W_{2}, W_{3}, W_{4}, W_{5}, W_{6}, W_{7}, W_{8}, W_{9}, W_{10}, W_{11}\right]^{T} . \\
& V_{i, j}=\left[V_{1,1}, V_{1,2}, \ldots, V_{i, j}\right] \\
& i=1,2, \ldots, 20 ; j=1,2, \ldots, 78
\end{aligned}
$$

The number of particles is 20, the length $L$ of the particle vector $X$ is 66 , and the velocity vector dimension of the particle is 78 . The maximum iteration step is 1000 .

The parameter optimization process is shown in Figure 7.

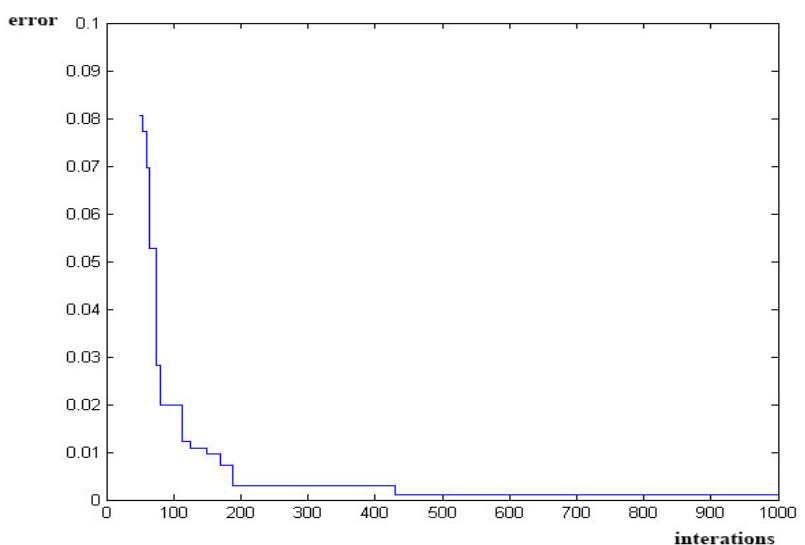

Figure 7. Best fitness optimization curse

The optimized position vector of the particle, the threshold and the network weight of the vector decoded by the vector are as follows: 


$\boldsymbol{X}=\left[\begin{array}{lllllll}0.8147 & 0.6557 & 0.4387 & 0.1749 & 0.706 & 0 \\ 0.9058 & 0.0357 & 0.3816 & 0.1386 & 0.645 & 1 \\ 0.1270 & 0.8491 & 0.7655 & 0.5989 & 0.5523 \\ 0.9134 & 0.9340 & 0.7952 & 0.9011 & 0.2181 \\ 0.6324 & 0.6787 & 0.1869 & 0.9394 & 0.7724 \\ 0.0975 & 0.7577 & 0.4898 & 0.2212 & 0.2280 \\ 0.2785 & 0.7431 & 0.4456 & 0.4827 & 0.3709 \\ 0.5469 & 0.3922 & 0.6463 & 0.3760 & 0.8909 \\ 0.9575 & 0.6555 & 0.7094 & 0.5238 & 0.8564 \\ 0.9649 & 0.1712 & 0.7547 & \cdots & 0.2649 & 0.402 & 4 \\ 0.1576 & 0.7060 & 0.2760 & 0.0684 & 0.3180 \\ 0.9706 & 0.0318 & 0.6797 & 0.4363 & 0.6086 \\ 0.9572 & 0.2769 & 0.6551 & 0.1739 & 0.9102 \\ 0.4854 & 0.0462 & 0.1626 & 0.0261 & 0.9091 \\ 0.8033 & 0.0971 & 0.1190 & 0.9547 & 0.5916 \\ 0.1419 & 0.8235 & 0.4984 & 0.4306 & 0.3326 \\ 0.4218 & 0.6948 & 0.9597 & 0.9616 & 0.8531 \\ 0.9157 & 0.3171 & 0.3404 & 0.7264 & 0.4424 \\ 0.7922 & 0.9502 & 0.5853 & 0.0073 & 0.9044 \\ 0.9559 & 0.0344 & 0.2238 & 0.6800 & 0.032\end{array}\right]$

$\boldsymbol{V}=\left[\begin{array}{lllllll}0.8147 & 0.1622 & 0.6443 & 0.3747 & 0.952 & 2 \\ 0.6557 & 0.1067 & 0.3111 & 0.4369 & 0.5433 \\ 0.4387 & 0.8530 & 0.0855 & 0.3043 & 0.2514 \\ 0.7531 & 0.7803 & 0.0377 & 0.2909 & 0.5786 \\ 0.3517 & 0.5470 & 0.0305 & 0.2425 & 0.9155 \\ 0.3219 & 0.5431 & 0.5323 & 0.9367 & 0.8956 \\ 0.4039 & 0.4390 & 0.2794 & 0.8602 & 0.4825 \\ 0.5486 & 0.2874 & 0.9462 & 0.3972 & 0.4427 \\ 0.0487 & 0.5017 & 0.9064 & 0.4794 & 0.3118 \\ 0.5527 & 0.7615 & 0.3927 & 0.5650 & 0.0553 \\ 0.2748 & 0.7624 & 0.0249 & \cdots & 0.4896 & 0.7538 \\ 0.2415 & 0.5761 & 0.6417 & 0.2698 & 0.1319 \\ 0.2431 & 0.7447 & 0.8372 & 0.9897 & 0.3559 \\ 0.1542 & 0.6455 & 0.9715 & 0.1837 & 0.3959 \\ 0.9564 & 0.1232 & 0.0569 & 0.8617 & 0.8855 \\ 0.9357 & 0.5044 & 0.4503 & 0.0326 & 0.0212 \\ 0.8187 & 0.3473 & 0.5825 & 0.3320 & 0.8441 \\ 0.7283 & 0.0921 & 0.6866 & 0.7487 & 0.2881 \\ 0.1758 & 0.1478 & 0.7194 & 0.6444 & 0.2503 \\ 0.3604 & 0.1982 & 0.6500 & 0.1692 & 0.4844\end{array}\right]$

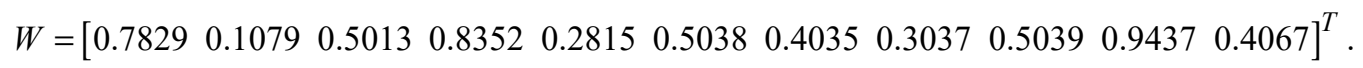

\subsection{Prediction result}

The BP neural network is replaced with QPSO optimized network parameter as the initial value of the parameter. After satisfying the training accuracy or the maximum training number, make the prediction. The predicted values and actual values are shown in Figure 8.

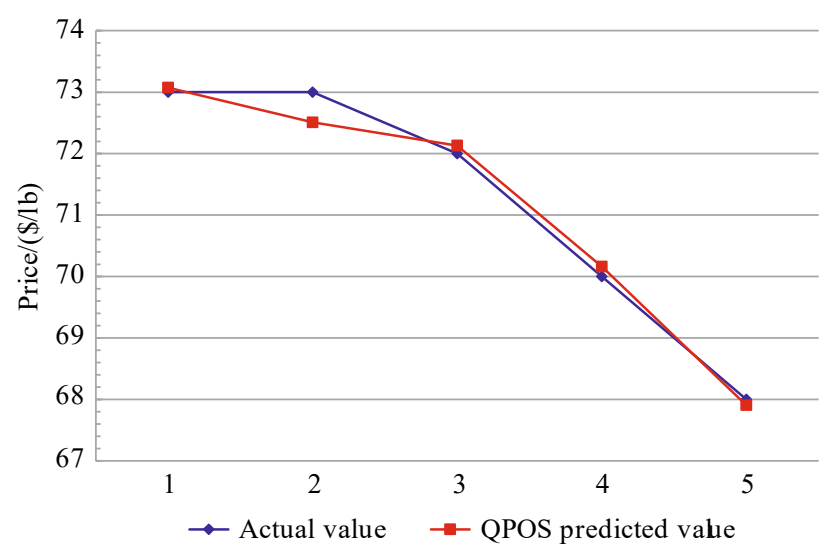

Figure 8. QPSO-BP model prediction results

Mean absolute percentage error (MAPE) is used to measure the accuracy of the prediction. The MAPE of the QPSO-BP model is $0.151 \%\left(\bar{\sigma}_{\mathrm{MAPE}}=0.151 \%\right)$.

The maximum accuracy is $0.26 \%$.

The uranium price is a complex nonlinear system affected by many factors. Based on the BP network, the improved QPSO algorithm is used to optimize and effectively predict the price of uranium.

\section{SYSTEM FEATURES}

MRTEEES is designed for business operations of mine enterprises. It is an auxiliary management system for technical and economic evaluation for it can provide decision making analysis and support project management. It mainly aims to provide the standardized mode- ling and evaluation process for enterprises characterized by having multiple mine categories, multistage projects, multiple mining methods and evaluation methods. It can perform project technical and economic evaluation and feasibility evaluation, including investment estimates, financial analysis, economic cost-benefit analysis, risk analysis and so on.

The project modeling process is made standardized. A model is set up by controlling the parameters inputting interface and setting the data positioning. The system can achieve automatic calculation, which saves the cumbersome work for constructing forms when establishing a new model.

Through uranium resources database management, a large number data can be collected and updated timely. As a result, the parameters are increasingly completed, which guarantees accuracy of the evaluation and analysis results. Enterprise and case data management, project data management and auxiliary data management make possible coding, accumulating and sharing of existing information.

The system is established based on $\mathrm{C} / \mathrm{B} / \mathrm{S}$ mixed mode and uses ASP.NET technology. The system makes full use of the Intranet and also the Internet and the business office area is expanded. By using Web Office, the system is fully compatible with spreadsheet and other kinds of document formats. It can automatically generate feasibility evaluation report, which largely reduces the complicated paperwork and thus improves work efficiency.

\section{CONCLUSIONS}

URTEEES achieves the functions of decision making analysis, uranium resources database management, data management, comprehensive query and so on. The standardized evaluation process helps horizontal comparison of all kinds of metal resources projects. Owning to completeness of the database, especially technical database, economic database and cost database, the feasibility eva- 
luation results is more accurate and the investment risk can be largely reduced. By expanding the database, this expert system can also be used by other businesses for technical and economic evaluation. The system can also provide important support for group investment activities.

Accuracy of the raw data is the basis for project investment evaluation. Thus, uranium resources database should be updated and perfected timely and regularly. Accuracy of the investment feasibility evaluation results depends more on completeness and accuracy of the basic data which are accumulated by storing the evaluation results of the existing projects through software interface. Thus, it's necessary to complete the basic data by making more evaluations with the software and accumulating relevant project data and experience.

\section{ACKNOWLEDGEMENTS}

This research project is made possible through the financial support from National Natural Science Foundation of China (No.51374242, No.51404305 and No.51504286).

\section{REFERENCES}

Castellanos, V., Albiter, A., Hernández, P., \& Barrera, G. (2011). Failure Analysis Expert System for Onshore Pipelines. Part - I: Structured Database and Knowledge Acquisition. Expert Systems with Applications, 38(9), 11085-11090. https://doi.org/10.1016/i.eswa.2011.02.153

Dymova, L., Sevastianov, P., \& Bartosiewicz, P. (2010). A New Approach to the Rule-Base Evidential Reasoning: Stock Trading Expert System Application. Expert Systems with Applications, 37(8), 5564-5576. https://doi.org/10.1016/j.eswa.2010.02.056

Ebersbach, S., \& Peng, Z. (2008). Expert System Development for Vibration Analysis in Machine Condition Monitoring. Expert Systems with Applications, 34(1), 291-299. https://doi.org/10.1016/j.eswa.2006.09.029

Ertl, L., \& Christ, F. (2007). Significant Improvement of the Quality of Bystander First Aid Using an Expert System with a Mobile Multimedia Device. Resuscitation, 74(2), 286-295. https://doi.org/10.1016/j.resuscitation.2007.01.006

Gong, Z., John, D., \& Gong, T. (2014). Advanced Expert Systems: Principles, Design and Applications. Beijing, China: Science Press.

Iqbal, A., He, N., Li, L., \& Dar, N. (2007). A Fuzzy Expert System for Optimizing Parameters and Predicting Performance Measures in Hard-Milling Process. Expert Systems with Applications, 32(4), 1020-1027.

https://doi.org/10.1016/j.eswa.2006.02.003
Kim, K.-S., Roh, M.-I., \& Ha, S. (2015). Expert System Based on the Arrangement Evaluation Model for the Arrangement Design of a Submarine. Expert Systems with Applications, 42(22), 8731-8744. https://doi.org/10.1016/j.eswa.2015.07.026

Koutsantonis, D., \& Panayiotopoulos, J.-C. (2009). Expert System Personalized Knowledge Retrieval. Operational Research, 11(2), 215-227. https://doi.org/10.1007/s12351-009-0048-4

Marlow, D., Gould, S., \& Lane, B. (2015). An Expert System for Assessing the Technical and Economic Risk of Pipe Rehabilitation Options. Expert Systems with Applications, 42(22), 8658-8668.

https://doi.org/10.1016/j.eswa.2015.07.020

Piltan, M., Mehmanchi, E., \& Ghaderi, S.F. (2012). Proposing a Decision-Making Model Using Analytical Hierarchy Process and Fuzzy Expert System for Prioritizing Industries in Installation of Combined Heat and Power Systems. Expert Systems with Applications, 39(1), 1124-1133. https://doi.org/10.1016/j.eswa.2011.07.112

Polat, K., \& Güneş, S. (2007). An Expert System Approach Based on Principal Component Analysis and Adaptive Neuro-Fuzzy Inference System to Diagnosis of Diabetes Disease. Digital Signal Processing, 17(4), 702-710. https://doi.org/10.1016/j.dsp.2006.09.005

Ruiz-Mezcua, B., Garcia-Crespo, A., Lopez-Cuadrado, J.L., \& Gonzalez-Carrasco, I. (2011). An Expert System Development Tool for Non AI Experts. Expert Systems with Applications, 38(1), 597-609.

https://doi.org/10.1016/j.eswa.2010.07.009

Šubelj, L., Furlan, Š., \& Bajec, M. (2011). An Expert System for Detecting Automobile Insurance Fraud Using Social Network Analysis. Expert Systems with Applications, 38(1), 1039-1052.

https://doi.org/10.1016/j.eswa.2010.07.143

Wan, S., Lei, T.-C., \& Chou, T.-Y. (2012). A Landslide Expert System: Image Classification Through Integration of Data Mining Approaches for Multi-Category Analysis. International Journal of Geographical Information Science, 26(4), 747-770. https://doi.org/10.1080/13658816.2011.613397

Wen, W. (2008). A Dynamic and Automatic Traffic Light Control Expert System for Solving the Road Congestion Problem. Expert Systems with Applications, 34(4), 2370-2381. https://doi.org/10.1016/j.eswa.2007.03.007

Wen, W. (2010). An Intelligent Traffic Management Expert System with RFID Technology. Expert Systems with Applications, 37(4), 3024-3035. https://doi.org/10.1016/j.eswa.2009.09.030

Zarandi, M.H.F., \& Ahmadpour, P. (2009). Fuzzy Agent-Based Expert System for Steel Making Process. Expert Systems with Applications, 36(5), 9539-9547.

https://doi.org/10.1016/j.eswa.2008.10.084

\section{СИСТЕМА ОЦІНЮВАННЯ РОЗВІДУВАЛЬНИХ І ГІРНИЧИХ РОБІТ, ПРОГНОЗУВАННЯ ЦІН ЗАПАСІВ УРАНУ}

\section{Я. Чен, Є. Жао, К. Сонг, Ж. Жоу, Ш. Янг}

Мета. Розробка експертно-аналітичної системи техніко-економічного оцінювання запасів урану з точки зору аналізу вимог, системи проектування, функціональної структури і напрямів застосування.

Методика. Проектна система повинна включати два основні блоки. Перший - існуючі дані щодо оцінки ресурсів урану для отримання відповідних параметрів, які можуть бути використані для створення моделей оцінки й забезпечення основи для їх порівняння при оцінці нового проекту. Другий - допоміжна інформація, така як закони і правила, культурна інформація, яка насправді $є$ накопиченням даних проекту і досвіду. Пропонована система заснована на використанні комбінованого режиму C/B/S; при цьому система використовує технологію ASP.NET c Net Framework, обрану в якості платформи розробки, а також базу даних по запасах урану, що забезпечує інформаційну підтримку на нижньому рівні. 
Результати. Розроблена нова система URTEEES виконує функції імовірнісного аналізу, аналізу чутливості, аналізу прибутковості для акціонерів, а також горизонтальне порівняння різних проектів, отже, може поліпшити результативність прийняття рішень керівниками проекту для швидкого реагування на дії конкурентів, крім того, дана система відповідає вимогам процесу ціноутворення. Реалізація проектної системи показує високу ефективність, оскільки включає в себе безліч методів з поліпшеними характеристиками, наприклад, модель QPSO-BP, яка удосконалила узагальнюючі можливості нейронної мережі ВР з метою оптимізації та ефективного прогнозування ціни на уран.

Наукова новизна. В системі розроблена модель техніко-економічного оцінювання в залежності від стадійності реалізації проекту (в основному, це стадія геологорозвідувальних робіт, стадія розробки родовища і стадія промислового видобутку), а також способу ведення гірничих робіт (наприклад, підземні гірничі роботи, відкриті гірничі роботи або ж роботи, пов'язані з підземним вилуговуванням), а результати оцінювання можна безпосередньо підрахувати і представити наочно у вигляді діаграм. Крім того, представляється можливим автоматично сформувати техніко-економічне обгрунтування, що дозволяє зробити процес техніко-економічного оцінювання точним і ефективним.

Практична значимість. Система URTEEES дозволяє виконувати функції аналізу процесу прийняття рішень, управління базою даних запасів металів, управління даними, універсальної пошукової системи в гірничодобувній промисловості.

Ключові слова: запаси урану, експертно-аналітична система, комбінований режим C/B/S, оптимізація згустку квантових частинок, алгоритм, модель QPSO-BP

\section{СИСТЕМА ОЦЕНИВАНИЯ РАЗВЕДОЧНЫХ И ГОРНЫХ РАБОТ, ПРОГНОЗИРОВАНИЕ ЦЕН ЗАПАСОВ УРАНА}

\section{Я. Чен, Е. Жао, К. Сонг, Ж. Жоу, Ш. Янг}

Цель. Разработка экспертно-аналитической системы технико-экономического оценивания запасов урана с точки зрения анализа требований, системы проектирования, функциональной структуры и применения.

Методика. Проектная система должна включать два основных блока. Первый - существующие данные об оценке ресурсов урана для получения соответствующих параметров, которые могут быть использованы для создания моделей оценки и обеспечения основы для их сравнения при оценке нового проекта. Второй - вспомогательная информация, такая как законы и правила, культурная информация, которая на самом деле является накоплением данных проекта и опыта. Предлагаемая система основана на использовании комбинированного режима $\mathrm{C} / \mathrm{B} / \mathrm{S}$; при этом система использует технологию ASP.NET c Net Framework, выбранную в качестве платформы разработки, а также базу данных по запасам урана, что обеспечивает информационную поддержку на нижнем уровне.

Результаты. Разработанная система выполняет функции вероятностного анализа, анализа чувствительности, анализа доходности для акционеров, а также горизонтальное сравнение различных проектов, следовательно, может улучшить результативность принятия решений руководителями проекта для быстрого реагирования на действия конкурентов; кроме того, данная система соответствует требованиям процесса ценообразования. Реализация проектной системы показывает высокую эффективность, поскольку включает в себя множество методов с улучшенными характеристиками, например, модель QPSO-BP, которая усовершенствовала обобщающие возможности нейронной сети ВР с целью оптимизации и эффективного прогнозирования цены на уран.

Научная новизна. В системе разработана модель технико-экономического оценивания в зависимости от стадийности реализации проекта (в основном, это стадия геологоразведочных работ, стадия разработки месторождения и стадия промышленной добычи), а также способа ведения горных работ (например, подземные горные работы, открытые горные работы или же работы, связанные с подземным выщелачиванием), а результаты оценивания можно непосредственно подсчитать и представить наглядно в виде диаграмм. Кроме того, представляется возможным автоматически сформировать технико-экономическое обоснование, что позволяет сделать процесс технико-экономического оценивания точным и эффективным.

Практическая значимость. Система URTEEES позволяет выполнять функции анализа процесса принятия решений, управления базой данных запасов металлов, управления данными, универсальной поисковой системы в горнодобывающей промышленности.

Ключевые слова: запасы урана, экспертно-аналитическая система, комбинированный режим C/B/S, оптимизация сгустка квантовых частии, алгоритм, модель QPSO-BP

\section{ARTICLE INFO}

Received: 2 November 2017

Accepted: 6 February 2018

Available online: 16 February 2018 


\section{ABOUT AUTHORS}

Jianhong Chen, Doctor of Philosophy, Professor of the School of Resources and Safety Engineering, Central South University, No.932, Lushan South Road, Yuelu District, 410083, Changsha, China. E-mail: cjh@263.net

Yifei Zhao, Master Degree Candidate of the Central South University, No.933, Lushan South Road, Yuelu District, 410084, Changsha, China. E-mail: 1206102513@qq.com

Qinghua Song, PhD Candidate of the Central South University, No.934, Lushan South Road, Yuelu District, 410085, Changsha, China. E-mail: qhsongcsu@163.com

Zhiyong Zhou, Doctor of Philosophy, Lecturer of the School of Resources and Safety Engineering, Central South University, No.935, Lushan South Road, Yuelu District, 410086, Changsha, China. E-mail: csuzzy@126.com

Shan Yang, Doctor of Philosophy, Lecturer of the School of Resources and Safety Engineering, Central South University, No.936, Lushan South Road, Yuelu District, 410087, Changsha, China. E-mail: 39911110@qq.com 